\title{
The Sustainable Development Goals and the Tourism and Hospitality Industry
}

\author{
By Peter Jones* \\ David Hillier ${ }^{*}$ \\ Daphne Comfort ${ }^{*}$
}

The purpose of this paper is to examine some of the challenges the tourism and hospitality industry may encounter in looking to contribute to the Sustainable Development Goals (SDGs) and to offer some wider reflections on sustainability within the industry. The SDGs provide a wide range of global sustainable development targets for the environment, society and economy and they were launched by the United Nations in 2015. In launching the SDGs while the United Nations called on all member states to embrace what are an ambitious and demanding set of challenges it also emphasised the vital role that business, would have to play if these challenges were to be met. The paper begins by outlining the SDGs and the case for business engagement with the SGDs, goes on to examines some of the challenges the tourism and hospitality industry may encounter in looking to contribute to the SDGs and offers some wider reflections on sustainability within the industry.

Keywords: Sustainable Development Goals, Tourism and Hospitality Industry, Business Engagement, Stakeholders, External Assurance, Economic Growth.

\section{Introduction}

In the five decades since the United Nations Conference on the Environment in Stockholm in 1971 sustainable development has proved a compelling but an elusive paradox (Adelson et. al 2016). Ramirez (2012), for example, has argued that this paradox reflects the tension between the potentially positive effects of economic growth on poverty and employment with the damaging impact of such growth on the environment's natural resources and on traditional societies and peoples' ways of life in many parts of the less developed world. In a similar vein on the one hand Adelson et.al. (2016) have argued that under the banner of sustainable development great strides have been made in protecting fragile environments, improving water supply and sanitation, installing irrigation systems and more generally in reducing poverty in many less developed economies. On the other hand Adelson et. al. (2016) argue that the ambiguous nature of sustainable development means that it can be used by a variety of organisations in the pursuit of their own vested interests.

\footnotetext{
* Professor of Management, Business School, University of Gloucestershire, Cheltenham, UK.

${ }^{\dagger}$ Emeritus Professor, Centre for Police Sciences, University of South Wales, Pontypridd, Wales, UK.

* Research Administrator, Business School, University of Gloucestershire, Cheltenham, UK.
} 
In many ways the launch of the Sustainable Development Goals (SDGs) are designed to provide some consensus and an all embracing common sense of purpose to sustainable development across the globe. The SDGs, agreed by the General Assembly of the United Nations in 2015 and adopted by the leaders of 193 member states, are a series of 17 goals (Table 1) and some 169 specific targets, which lay out the priorities for sustainable development for both developed and developing countries. In launching the SDGs the United Nations acknowledged the strategic political and major financial commitments required from all national governments but also effectively mandated the global business community to play a central role in achieving these goals. The tourism and hospitality industry is one of the driving forces in the global economy and it has a wide range of environmental and social impacts. With this in mind this commentary paper provides an outline of the SDGs, examines some of the challenges the tourism and hospitality industry may encounter in looking to contribute to the SDGs and offers some wider reflections on sustainability within the industry.

\section{The Sustainable Development Goals and Business Engagement}

The SDGs are central to the United Nations 2030 Agenda for Sustainable Development and embrace a wide range of environmental, social and economic issues, problems and challenges across most areas of human activity. More specifically, for example, the SDGs include ending hunger, achieving food security and the promoting sustainable agriculture; ensuring inclusive and equitable education and promoting lifelong learning for all; promoting sustainable and inclusive economic growth; ensuring access to affordable and reliable energy for all; ensuring the availability of water and sanitation for all; and achieving gender equality and the empowerment of women and girls. In announcing the launch of the SDGs the United Nations explicitly called on businesses to play a central role by harnessing their creativity to address the challenges posed by its new sustainable development agenda.

On the one hand and by way of a positive response to this call Corporate Citizenship (2015) has argued that the SDGs present a wide range of opportunities for businesses and suggested that there is a strong threefold business case for the SDGs. Firstly the development of innovative products and services designed to meet the SDGs, will lead to new revenue streams. Secondly where businesses looked to align commercial strategies and sustainability policies with the SDGs this will effectively enhance their license to operate. Thirdly companies will be able to form partnerships with governments, non-governmental organisations and other companies to build stronger relationships in important markets. On the other hand PricewaterhouseCoopers (2015) suggested that business engagement with the SDGs will make unfamiliar and potentially unwelcome demands on businesses which could, in turn, lead to a fundamental review and reappraisal of corporate strategies. Arguably more critically the Institute for Human Rights and 
Business (2015) argued that it is somewhat naïve for the United Nations to assert that businesses will become the new agents of development by pursuing new models of economic growth that will provide the panacea for poverty, inequality and environmental and natural resource degradation.

The tourism and hospitality industry has become a major player in the world economy. Geographically it now has global reach and as such it generates a wide range of environmental, social and economic impacts. Increasingly many of the major players within the industry have adopted corporate sustainability strategies, designed to manage their impacts on the environment, societies and economies. Many of the large companies now report annually on their achievements against strategic goals. Jones et. al. (2015), for example, outlined the growing interest in corporate sustainability within the hospitality industry and offered a review of the range of academic research into sustainability within that industry. More specifically Jones et.al. (2014) examined how the leading global hotel companies provide information on a variety of environmental, social and economic commitments to sustainability whilst de Grosbois (2016) reviewed the corporate social responsibility reporting behaviour of the leading ocean cruise companies. As such the tourism and hospitality industry can potentially be seen as a major player amongst businesses contributing to the SDGs. The United Nations World Tourism Organisation (UNWTO) for example, suggested that 'tourism has the potential to contribute, directly or indirectly, to all of the goals' (UNWTO 2015). In a similar vein the UNWTO and the Pacific Asia Travel Association (2015) argued that 'achieving the SDGs must now become the over-arching agenda of global tourism' and that 'the tourism sector is perhaps better placed than any other industry to contribute to the cause across the board.'

The UNWTO have argued that the tourist and hospitality industry can contribute to the realisation of the SDGs while developing a wide range of market opportunities. In addressing Goal 1, for example, the UNWTO suggested that 'as one of the largest and fastest growing economic sectors in the world, tourism is well-positioned to foster economic growth and development at all levels and provide income through job creation' (UNWTO 2015). In outlining the industry's contribution to Goal 2, the UNWTO argued that 'tourism can spur agricultural productivity by promoting the production, use and sale of local produce in tourist destinations and its full integration in the tourist value chain' and that 'the resulting rise in income in local communities can lead to a more resilient agriculture while enhancing the value of the tourism experience' (UNWTO 2015). In addressing Goal 13 the UNWTO recognised that 'tourism contributes to and is affected by climate change' and stressed that 'it is therefore in the sector's own interest to play a leading role in the global response to climate change' and that 'by lowering energy consumption and shifting to renewable energy sources, particularly in the transport and accommodation sector, tourism can help to tackle one of the most pressing challenges of our time' (UNWTO 2015). 


\section{Challenges for the Tourism and Hospitality Industry}

While the tourism and hospitality industry can be seen to have a vital role to play in the drive towards a more sustainable future the leading players within the industry must address a number of challenges as they look to make a meaningful contribution to the achievement of the SDGs. The leading players within the tourism and hospitality industry face challenges, for example, in determining which of the 17 SDGs (and the 169 associated targets) they select and prioritise. Across the business world large companies increasingly employ a range of internal and external stakeholder engagement activities to determine materiality, namely to identify and prioritise the environmental, social and economic issues which inform their sustainability strategies. A number of the leading players within the global hotel industry have looked to engage with their stakeholders in developing their sustainability strategies. Wyndham Worldwide (2011), for example, emphasised that its stakeholders 'are significant drivers of our sustainability program' and that its 'shareholders keep us focused to make a difference and to drive for results.' In a similar vein Marriot (2012) argued that its stakeholders play an important role in 'helping to shape our sustainability strategy.' More specifically Royal Caribbean Cruises (2015), for example, outlined the methodology employed to define the content of its sustainability report. This process began with the identification of stakeholders and the selection of 42 economic, environmental, labour practices, human rights, social and product responsibility impacts and issues. The company reported undertaking a wide ranging internal corporate assessment of all these issues and impacts in order to identify the most important issues for the company's operations. The company then surveyed a range of external stakeholders, including passengers and crew members as well as several nongovernmental organisations to inform the development of its sustainability strategy.

However Williams and Ponsford (2009) acknowledged evidence of 'growing knowledge concerning how to move tourism towards greater sustainability' but argued that 'progress in transitioning from concepts and principles to pan-industry practice is limited' and suggested that in some ways this reflects the absence of 'collective leadership amongst tourism's stakeholders.' More specifically in reviewing sustainability reporting amongst ocean cruising companies Bonilla-Priego et.al (2014) suggested 'companies disclose more management than performance data', that many companies often 'focus on soft indicators which are easy to mimic and demonstrate posturing' and arguably more critically that 'reports echo the voice of the corporations and not the demands of stakeholders. This is perhaps indicative of a generic concern in the identification and prioritisation of materiality concerning the nature of the relationship between the interests of the company and those of external stakeholders. Where companies, and more specifically their executive management, are principally responsible for identifying and determining materiality, then strategic corporate goals rather than a strong 
commitment to sustainability per se or to the SDGs, may well, inevitably hold sway.

The major tourism and hospitality companies may be faced with the dilemma whether or not to develop new sustainability strategies and targets specifically to meet a number of the SDGs or whether simply to map their existing strategies onto the SDGs. In general terms the UNWTO has outlined how tourism can contribute to each of the SDGs but during the past decade many of the large companies within the industry have been developing and refining their sustainability strategies and at present they may be highly unlikely to go back to the drawing board to develop new strategies more specifically attuned to the the SDGs. In addressing the mapping of SDGs to business activity PricewaterhouseCoopers (2015) suggested that 'the tools to map SDGs to a business currently don't exist' and that while some companies were developing their own methodologies 'consistency of approach was lacking.' At the same time multinational companies may face challenges in developing overall corporate sustainability strategies in the face of different government approaches to the prioritisation of the SDGs in different parts of the world.

Although many large companies often claim that their sustainability reports follow Global Reporting Initiative G4 guidelines their approach to independent external assurance often seems to be limited and/or confined to a small range of sustainability issues and targets. Jones et. al. (2014), for example, found little evidence of independent external assurance of the information on sustainability posted by the leading global hotel companies. In a similar vein an examination of the external assurance undertaken by two leading ocean cruising companies revealed that Royal Caribbean Cruises provided no details of the assurance process they reported having commissioned while the external assurance exercise reported by the Carnival Corporation was limited both in its scope and in that it covered only greenhouse gas emissions and ignored all the other sustainability issues deemed to be material by the company (Jones et. al. 2016). The lack of more comprehensive independent external assurance of the sustainability reporting process within the tourism and hospitality industry is not a problem in itself in that sustainability reporting is currently a voluntary process and assurance statements are currently not subject to statutory regulation. However the lack of comprehensive independent assurance can be seen to undermine the credibility, integrity and utility of the sustainability reporting process. In looking to the future if companies are to publicly demonstrate and measure their commitment and contribution to the SDGs then the independent assurance of all the data included in sustainability reports would seem to be essential.

\section{Discussion}

The speed and extent of the leading tourism and hospitality companies' responses to the challenges outlined above will be important in determining the 
industry's contribution to the SDGs but five more general issues merit reflection and attention. Firstly here are issues about the way in which many of the major players in the tourism and hospitality industry implicitly define sustainability and construct their sustainability agendas. In reality the tourism and hospitality industry has made only limited explicit attempts to define sustainability or sustainable development. The most widely used definition of the concept of sustainable development is 'development that meets the needs of the present without compromising the ability of future generations to meet their own needs' (World Commission on Environment and Development 1987). More specifically the concept is widely seen to encompass both the essential needs of world's poorer nations and peoples, to which priority should be given and limitations on the environment's ability to meet existing and future needs. That said sustainability is a contested concept and as Aras and Crowther (2008) have argued 'sustainability is a controversial topic because it means different things to different people.' There is a family of definitions essentially based in and around ecological principles and there are definitions which include social and economic development as well as environmental goals and which seek to embrace equity in meeting human needs. At the same time a distinction is often made between 'weak' and 'strong' sustainability with the former being used to describe sustainability initiatives and programmes developed within the existing prevailing economic and social system while the latter is associated with much more radical changes for both economy and society.

Although the majority of the leading players in the tourism and hospitality industry publicly emphasise their commitment to corporate sustainability the dominant definition within the industry is built around business imperatives, business efficiency and cost savings rather than by any fundamental concern for sustainability. Thus while many of the environmental agendas addressed within the industry aim to produce reductions in energy use, water consumption and waste emissions they also help to reduce costs. In a similar vein the leading tourism and hospitality companies' commitments to their employees focusing for example, upon good working conditions, health and safety at work and training all help to promote stability and corporate commitment amongst the workforce. As such definitions of sustainability within the tourism and hospitality industry can be seen to emphasise a business continuity model which provides 'an invaluable tool for exploring ways to reduce costs, manage risks, create new products, and drive fundamental internal changes in culture and structure' (Azapagic 2003).

Secondly corporate sustainability is increasingly linked with the concept of shared value, typically defined as 'policies and practices that enhance the competitiveness of a company while simultaneously addressing the economic and social conditions in the communities in which it operates'(Porter and Kramer 2011). Hotel Analyst (2012), a consultancy which specialises in meeting the needs of the hotel investment community, argued that the concept of shared value had been adopted by a number of major international hotel companies and Porter (2012) mapped shared value in the tourism industry in Cairns, Australia. However Crane et. al. (2014) identified a number of 
weaknesses and shortcomings in the creation of the shared value model. More specifically Crane et. al. (2014) argued that the model fails to recognise what are often major tensions between economic and social goals and that it is rooted in what is essentially a shallow view of the role of business within society. In examining the first of these concerns, for example, Crane et. al. (2014) suggested that 'many corporate decisions related to social and environmental problems, however creative the decision-maker may be, do not present themselves as potential win-wins, but rather manifest themselves in terms of dilemmas.' As such Crane et. al. (2014) suggested that such dilemmas are effectively struggles between companies and their stakeholders over limited resources. In justifying their assertion that creating shared value is based on a shallow reading of the corporation's role in society Crane et. al. (2014) argued that the model seeks to 'rethink the purpose of the corporation without questioning the sanctity of corporate self-interest.'

Thirdly there are fundamental tensions between sustainability and continuing economic growth. On the one hand the leading global hotels' position on sustainability and growth might be seen to be epitomised by Marriott, for example, in that it reports that its 'sustainability goals support business growth' while IHG recognises the tension between the continuing growth of tourism and the environment but argues that this 'creates a space for innovation 'and suggests that this tension provides 'an opportunity to find innovative solutions to the environmental, social and economic effects of our business.' On the other hand World Travel Market (2016) has posed the question 'When will the tourist industry start talking sensibly about growth?' More specifically, Conscious. Travel (2016) argued 'the challenges facing humanity in general and the tourism/hospitality sector in particular stem from a failure to recognise that the current version of the economic system has, contained within it, structural and systemic flaws, that result in success (as in continued growth) becoming the cause of its own demise.' Furthermore, Conscious. Travel (2016) suggested that 'as far as destinations are concerned growth is currently defined in quantitative terms (more visitors, more spending, more GDP, more jobs) but not in terms of net positive outcome for all stakeholders" and that 'success is defined as "more" not as "better" regardless of how that better is distributed amongst stakeholders.'

Fourthly while responsible consumption and production is one of the SDGs it is a particularly elusive goal and the European Environment Agency (2016), for example, has described 'unsustainable consumption' as 'the mother of all environmental issues.' That said the UNWTO argued that 'a tourism sector that adopts sustainable consumption and production practices can play a significant role in accelerating the global shift towards sustainability' but here again there is no attempt to define sustainable consumption and production or to provide specific large scale examples of how sustainable consumption and production may be extensively and profitably incorporated into the industry's global operations. Within many developed economies there is currently little obvious evidence of consumer appetite for sustainable consumption and here the European Commission's (2012) has suggested that 
many people, essentially see sustainable consumption a step backwards rather than an important step forward towards a more sustainable future.

Finally technology and technological innovation are often seen to be vitally important in improving efficiency across the sustainability spectrum and in helping to deliver sustainable growth. Clark and Dickson (2003) suggested that 'the need for sustainable development initiatives to mobilize appropriate science and technology has long been recognized' and advances in technology are often seen to provide the best solution to promoting greater efficiency. More recently the Earth Institute Columbia University and Ericsson (2015), for example, argued that harnessing the power of Information Communications Technology will be vitally important in helping to achieve the SDGs. A number of the leading players within the tourism and hospitality industry have certainly stressed the importance of technological innovation in improving efficiency across the sustainability spectrum. The Intercontinental Hotel Group (2016), for example stressed its focus on seeking to innovate concepts and technologies' and reports, for example, that it is committed 'to designing, building and operating more sustainable hotels through innovation.' In looking to address and manage greenhouse gas emissions, Royal Caribbean Cruises (2015) reported on its plans to reduce overall energy use, to invest in emissions abatement technology and to utilize alternative fuels and energy sources. That said Huesemann (2003) has argued that technological innovation alone will not bring about a transition to sustainability and that unless continuing growth in both population and consumption is restrained technology may only temporarily delay the onset of increasingly severe environmental and social problems.

\section{Conclusion}

In launching the SDGs the United Nations has set a wide range of ambitious global targets to drive the transition to a more sustainable future and has called on all businesses to play a central role in achieving these targets. Here the underlying aim is to connect business strategies to global priorities for both people and the planet. Potentially the leading companies within the tourism and hospitality industry are in a powerful position to contribute to the successful achievement of the SDGs. However if the industry is to play an important role in promoting the transition to a more sustainable and equitable future sustainable, the leading players within the industry will face a number of challenges to the way they currently conceptualise and manage their sustainability strategies and their sustainability reporting processes. In looking to address these challenges the leading players within the industry may be well advised to develop a coherent, co-ordinated and proactive approach to the SDGs and to effectively communicate their approach to all their stakeholders. As such the industry could then be seen to be leading on, rather than reacting to, sustainability issues and to be helping to define and provide solutions to 
those issues. However concerns about fundamental tensions that exist between sustainability and continuing economic growth seem likely to persist.

Table 1. The Sustainable Development Goals

1. End hunger, achieve food security and improved nutrition and promote sustainable agriculture

2. Ensure healthy lives and promote well-being for all at all ages

3. Ensure inclusive and equitable quality education and promote lifelong learning opportunities for all

4. Achieve gender equality and empower all women and girls

5. Ensure availability and sustainable management of water and sanitation for all

6. Ensure access to affordable, reliable, sustainable and modern energy for all

7. Promote sustained, inclusive and sustainable economic growth, full and productive employment and decent work for all

8. Build resilient infrastructure, promote inclusive and sustainable industrialization and foster innovation

9. Reduce inequality within and among countries

10. Make cities and human settlements inclusive, safe, resilient and sustainable

11. Ensure sustainable consumption and production patterns

12. Take urgent action to combat climate change and its impacts

13. Conserve and sustainably use the oceans, seas and marine resources for sustainable development

14. Protect, restore and promote sustainable use of terrestrial ecosystems, sustainably manage forests, combat desertification, and halt and reverse land degradation and halt biodiversity loss

15. Promote peaceful and inclusive societies for sustainable development, provide access to justice for all and build effective, accountable and inclusive institutions at all levels

16. Promote, just, peaceful and inclusive societies

17. Strengthen the means of implementation and revitalize the global partnership for sustainable development

Source United Nations 2015a

\section{References}

Adelson, G. (2016) 'Environment: An Interdisciplinary Anthology', http://www.envi ronmentanthology.org/index.php/concepts-a-case-studies/ch-5-the-paradox-ofsustainable-development/295 (Accessed 21 November 2016).

Aras, G. and Crowther, D. (2008) 'Governance and Sustainability: An investigation into the relationship between corporate governance and corporate sustainability', Management Decision Vol. 46, No. 3, pp.433-448

Azapagic, A. (2003) 'Systems Approach to Corporate Sustainability', Transactions of the Institute of Chemical Engineers, Vol. 81 Part b, pp.303-316 
Bonilla-Priego, M.J., Font, X. and Pacheco-Olivares, M del R (2014), 'Corporate sustainability reporting index and baseline data for the cruise industry', Tourism Management, Vol. 44, pp. 149-160

Clark, W.C. and Dickson, N.M. (2003) 'Sustainability science: The emerging research program', Proceedings of the National Academy of Sciences in the United States of America, Vol. 14, No. 4, pp. 8059-8061, http://www.pnas.org/content/ 100/14/8059.full (Accessed 10 November 2014)

Conscious. Travel (2016) 'Towards Opening a Sensible Debate on Tourism Growth', https://conscious.travel/2016/04/22/towards-opening-a-sensible-debate-on-tour ism-growth/ (Accessed 15 May 2016)

Corporate Citizenship (2015) 'From My World to Our World: What the Sustainable Development Goals Mean for Business', http://corporate-citizenship.com/our-in sights/from-my-world-to-our-world-what-the-sdgs-mean-for-business/ (Accessed 12 October 2016)

Crane, A., Palazzo, G., Spence, L.J. and Matten, D. (2014) 'Contesting the Value of Creating Shared Value', California Management Review, Vol. 56, No. 2, pp. 130-154

de Grosbois, D. (2016) 'Corporate Social Responsibility Reporting in the Cruise Tourism Industry: A Performance Evaluation using a New Institutional Theory Based Model,' Journal of Sustainable Tourism, Vol. 24, No. 2, pp. 245-269

European Environment Agency (2016) 'Unsustainable Consumption: The Mother of All Environmental Issues', http://www.eea.europa.eu/highlights/unsustainableconsumption-2013-the-mother (accessed 29 November 2016).

European Commission (2012) 'Policies to Encourage Sustainable Consumption', http://ec.europa.eu/environment/archives/eussd/pdf/report_22082012.pdf (Acces sed 3 February 2016)

Hotel Analyst ((2012) 'The Value of Sustainability for the Hotel Sector', http://hotela nalyst.co.uk/wp-content/uploads/sites/2/ha\%20hotel\%20sustainability\%20sam ple.pdf (Accessed 7 November 2016)

Huesemann, M. H. (2003) 'The Limits of Technological Solutions to sustainable Development', Clean Technologies and Environmental Policies, Vol. 5, No, 1, pp.21-34

Institute for Human Rights and Business (2015) 'State of Play-Business and the Sustainable Development Goals: Mind the Gap - Challenges for Implementation', http://www.ihrb.org/media/images/reports/state_of_play_report-business_and_ the_sdgs.pdf (Accessed 28 May 2016)

Intercontinental Hotel Group G (2016) 'Corporate Responsibility', https://www.ihgpl c.com/responsible-business/corporate-responsibility (Accessed 11 November 2104)

Jones, P. Comfort, D. and Hillier, D. (2016) 'Sustainability and the World's Leading Cruising Companies', Public Affairs, http://onlinelibrary.wiley.com/doi/10.1002/ pa.1609/full (Accessed 14 November 2016)

Jones, P., Hillier, D. and Comfort, D. (2014) 'Sustainability in the Global Hotel Industry', International Journal of Contemporary Hospitality Management', Vol. 26, No. 1, pp. 5-17

Jones, P., Hillier, D. and Comfort, D. (2015) 'Sustainability in the Hospitality Industry: Some Personal Reflections on Corporate Challenges and Research Agendas', International Journal of Contemporary Hospitality Management', Vol. 28 , No. 1, pp.36-67 
Marriott (2012) '2011-2012 Sustainability Report' http://www.marriott.com/Multi media/PDF/CorporateResponsibility/MarriottSustainabilityReport_2011and2012c ondensed4MB.pdf (Accessed 11 November2014)

PricewaterhouseCoopers (2015) 'Making It Your Business; Engaging with the Sustainable Development Goals', https://www.pwc.com/gx/en/sustainability/ SDG/SDG\%20Research_FINAL.pdf (Accessed 28 May 2016)

Porter, M. E. (2012) 'The New Competitive Advantage: Creating Shared Value', http://www.hbs.edu/faculty/Publication\%20Files/20121009\%20-\%20UDEM\% 20CSV\%20Presentation\%20-\%20FINAL\%20for\%20Distribution_6be7f280-6a 23-4b86-bcee-9af706c7ed5c.pdf (Accessed 12 November 2014)

Porter. M. E. and Kramer, M. R. (2011) 'Strategy and society: the link between competitive advantage and corporate social responsibility', Harvard Business Review, Vol. 87, pp. 78-92

Ramirez, G. A. (2012) 'Sustainable Development: Paradoxes, Misunderstandings and Learning Organisations', The Learning Organisation', Vo. 19, No. 1, pp. 58-76

Royal Caribbean Cruises (2015) '2014 Sustainability Report', http://www.rclcorpo rate.com/content/uploads/2014-RCL-Sustainability-Report.pdf (Accessed 15 March 2016)

The Earth Institute Columbia University/Ericcson (2015) 'How Information and communications Technology Can Achieve the Sustainable Development Goals', https://www.ericsson.com/res/docs/2015/ict-and-sdg-interim-report.pdf (Accessed 2 November 2016)

United Nations World Tourism Organisation (2015) 'Tourism and the Sustainable Development Goals', http://cf.cdn.unwto.org/sites/all/files/pdf/sustainable_deve lopment_goals_brochure.pdf (Accessed 13 October 2013)

United Nations World Tourism Organisation/ Pacific Asia Travel Association (2015) 'Global Trends Shaping Tourism in Asia Pacific', http://www.hotelsandtravel ler.com/review/unwtopata-report-\%E2\%80\%9Cglobal-trends-shaping-tourism-in -asia-pacific\%E2\%80\%9D.html

Williams, P.W. and Ponsford, I. F. (2009) 'Confronting tourism's environmental paradox: Transitioning for sustainable tourism', Futures, Vol. 41, pp. 396-404

World Commission on Environment and Development (1987) 'Our Common Future', http://www.un-documents.net/ocf-02.htm (Accessed 30 July 2014)

World Travel Market (2016) 'When will tourism industry start talking sensibly about growth', http://news.wtmlondon.com/blog/responsible-tourism/when-will-touris m-industry-start-talking-sensibly-about-growth/ (Accessed 12 May 2016)

Wyndham Worldwide (2011) 'Sustainability Report July 2011', http://www.wyndha mworldwide.com/sites/pdfs/green/Final-Wyndham-Sustainability-Report-July2011.pdf (Accessed 11 November 2104) 
